
\title{
28 Research Suare \\ Holoprosencephaly and other morphological abnormalities in the silky shark Carcharhinus falciformis
}

\section{Darren Andrew Whitehead}

Pelagios Kakunja A.C https://orcid.org/0000-0002-0984-0079

\section{Edgar Becerril-GarcíaA}

Instituto Politécnico Nacional, Centro Interdisciplinario de Ciencias Marinas https://orcid.org/00000002-1173-2309

\section{James Thomas Ketchum}

Pelagios Kakunja A.C https://orcid.org/0000-0002-7340-4749

\section{Amy hudson Weaver}

Sociedad de Historia Natural Niparajá, A.C

\section{Tomas Plomozo Lugo}

Sociedad de Historia Natural Niparajá, A.C

\section{Felipe Galván-Magaña}

Instituto Politécnico Nacional, Centro Interdisciplinario de Ciencias Marinas https://orcid.org/00000002-7613-4617

Mauricio Hoyos-Padilla ( $\square$ amuakua@gmail.com )

Pelagios Kakunja A.C https://orcid.org/0000-0002-4318-2655

\section{Short Report}

Keywords: Carcharhinidae, anatomical deformities, holoprosencephaly, prognathism, X-ray, Gulf of California

Posted Date: July 2nd, 2021

DOI: https://doi.org/10.21203/rs.3.rs-675795/v1

License: (c) (1) This work is licensed under a Creative Commons Attribution 4.0 International License. Read Full License 


\section{Abstract}

This study constitutes the first descriptions of morphological abnormalities in the silky shark Carcharhinus falciformis from a near term embryo obtained in the Gulf of California, Mexico. External exploration and X-ray images were taken to describe the specimen, which revealed that the embryos deformities were located in the cephalic region suggesting a holoprosencephaly disorder. The analyzed images evidenced a deformed oval chondrocranium with both nasal capsules pointing upwards and the rostrum pointing downwards, in which the palatoquadrate cartilage was deformed with signs of prognathism.

\section{Introduction}

The silky shark Carcharhinus falciformis (Müller \& Henle, 1839) is an abundant species that inhabits ocean basins worldwide (Compagno, 1984; Bonfil, 2009). Traditionally, the silky shark has been highly captured by fisheries, either as a target or as a bycatch species. In the Gulf of California, it is mainly caught by artisanal fishers through the use of longlines and gillnets (Cabrera-Chavez-Costa et al., 2010). The silky shark is a placental viviparous species with a gestation period of 11-12 months. According to previous studies in the Gulf of California, the pups born are born measuring $60-80 \mathrm{~cm}$ total length (TL), with a range of 2-9 embryos per offspring (Hoyos-Padilla et al., 2011). However, studies of deformations in sharks have been scarce given that embryos are usually discarded by fishers during their commercial activities. The present study provides evidence of the first case of morphological abnormalities in $C$. falciformis from an unborn specimen in the Gulf of California.

\section{Materials And Methods}

A near term embryo of $C$. falciformis was obtained from a pregnant female caught on September 6th, 2020. The female was captured near San Jose Island, to the north of La Paz Bay in the Gulf of California, Mexico $\left(24^{\circ} 08^{\prime} 32 \mathrm{~N}-110^{\circ} 18^{\prime} 39 \mathrm{~W}\right)$. The embryo was found in the uterus with other siblings and the deformity was discovered when the fishermen opened the female to remove internal organs. No Ethics procedures were required as the specimen was obtained by local artisanal fishers as a bycatch.

\section{Results}

The embryo showed normal pigmentation and external morphological characteristics of a healthy individual (Fig. 1b, c, d), but the snout was blunt, lacked nostrils, exhibited both eyes in front remarkably close to each other, and nictitating membranes were not functional suggesting a potential holoprosencephaly disorder (Fig. 1a). The X-radiography revealed that the embryos deformities were located in the cephalic region since the vertebrae did not show any thorax scoliosis or other deformities (Fig. 1e). These images from the head revealed a deformed oval chondrocranium suggesting a holoprosencephaly disorder with both nasal capsules pointing upwards and the rostrum pointing downwards. The palatoquadrate cartilage was deformed with signs of prognathism which refers to a 
protruding jaw (Fig. 1f). The Meckel's cartilage looked normal with multiple rows of teeth visible in both jaws. Dorsal X-radiography images from the head revealed a rounded precerebral cavity and rostrum pointing downwards resulting in the blunt shape of the head. Insertion of the vertebral spine in the foramen magnum looks normal. The gill arches look deformed and different in each side of the head. The pericardial cavity looks normal (Fig. 1e).

\section{Discussion}

The true cause of anatomical deformation in elasmobranchs is still unclear but could be attributed to a number of possibilities such as bad nutrition, parasitic infection or the accumulation of contaminants or pollutants in the pregnant female (Rodríguez-Romero et al., 1990; Heupel et al., 1999; Delpiani et al., 2011). In the Gulf of California, at least two species of shark have been reported with embryos showing evident deformities in the head. Other species of the genus Carcharhinus such as the dusky shark Carcharhinus obscurus have evidenced deformed embryos in this area, in which cyclopia was the most evident deformation along with albinism, absence of nostrils, and slight modifications of both the snout and the spine (Bejarano -Árvarez, et al., 2012). In addition to albinism, embryos of the Pacific angel shark Squatina californica have also presented partial cyclopia also known as synophthalmia (EscobarSánchez et al., 2013).

Records in the area may be related to negative effects of high concentrations of pollutants recorded in some parts of the Gulf of California, although this type of analysis has not been carried out on the specimens analysed so far (Escobar-Sánchez et al., 2013; Consales and Marsili, 2021). Caution must be recommended when assigning a clear cause of elasmobranch deformities from a single specimen, especially when additional foetuses in the mother show normal anatomical structure, as in this case. Continued documented evidence of anomalies in elasmobranchs remain rare and exposes the need to strengthen the bonds between the fisher communities and scientists to recover specimens as a way to improve our understanding of anatomical deformities.

\section{Declarations}

\section{Acknowledgments}

The authors would like to thank the fishers, fishery technicians, employees of Pescaderia COMERMAR (Karla Lezith Arias Garcia, Juana Garcia Posada, Ricardo Bravo Licona) and staff of Niparajá for donating the specimen as well as to Hospital Veterinario Dogtor House for the support during X-ray. F.G.M. thanks Instituto Politécnico Nacional for funding through grants from the Comisión de Operación y Fomento de Actividades Académicas and the Estímulo al Desempeño de los Investigadores, while EEBG thanks CONACyT for the scholarship provided. E.M.H.P and J.T.K. thanks to Alianza WWF-Fundación Telmex Telcel, Alianza WWF-Fundación Carlos Slim and Ocean Blue Tree, for their sponsor in the Gulf of California. 


\section{Conflicts of Interest}

The authors declare that they have no conflicts of interest.

\section{References}

Bejarano-Álvarez, O. M., \& Galván-Magaña, F. (2013). First report of an embryonic dusky shark (Carcharhinus obscurus) with cyclopia and other abnormalities. Marine Biodiversity Records, 6.

Bonfil, Ramón. (2009). The Biology and Ecology of the Silky Shark, Carcharhinus falciformis. 10.1002/9781444302516.ch10.

Food habits of the silky shark Carcharhinus falciformis (Müller \& Henle, 1839) off the western coast of Baja California Sur, Mexico, Journal of Applied Ichthyology, 26, 499-503

Cabrera-Chávez-Costa, A., Galván-Magaña, F., \& Escobar-Sánchez, O. (2010). Food habits of the silky shark Carcharhinus falciformis (Müller \& Henle, 1839) off the western coast of Baja California Sur, Mexico. Journal of Applied Ichthyology. 26. 499 - 503.

Clarke C., Lea J. S. E., Ormond R. F. G. (2011). Reef-use and residency patterns of a baited population of silky sharks, Carcharhinus falciformis, in the Red Sea. Marine and Freshwater Research 62, 668-675.

Compagno, L. J. V. (1984). FAO species catalogue. Vol. 4. Sharks of the World. An annotated and illustrated catalogue of shark species known to date. Part 2. Carcharhiniformes. FAO Fisheries Synopsis 4, 470-472.

Compagno, L.J.V., Dando, M. \& Fowler, S. 2005. Sharks of the world. Princeton University Press, New Jersey.

Consales, G. \& Marsili L. 2021. Assessment of the conservation status of Chondrichthyans: underestimation of the pollution threat. The European Zoological Journa/ 88:1, 165-180

Delpiani, Matias \& Deli Antoni, Mariana \& Barbini, Santiago \& Figueroa, Daniel. (2011). First record of a dicephalic specimen of tope Galeorhinus galeus (Elasmobranchii: Triakidae). Journal of fish biology. 78. 941-4. 10.1111/j.1095-8649.2010.02890.x.

Escobar-Sánchez, O., Moreno-Sánchez, X. G., Aguilar-Cruz, C. A., \& Abitia-Cárdenas, L. A. (2014). First case of synophthalmia and albinism in the Pacific angel shark Squatina californica. Journal of Fish Biology, 85(2), 494-501.

Heupel, M. R., Simpfendorfer, C. A., and Fitzpatrick, R. (2010). Large-scale movement and reef fidelity of grey reef sharks. Public Library of Science ONE 5(3), e9650. 
Hoyos-Padilla, E. M., Ceballos-Vázquez, B. P., \& Galván-Magaña, F. (2012). Reproductive biology of the silky shark Carcharhinus falciformis (Chondrichthyes: Carcharhinidae) off the west coast of Baja California Sur, Mexico. Journal of Applied Ichthyology, 18, 15-24.

Rodríguez-Romero, J., Ramírez-Sevilla, R. \& Nunez-Márquez, G. (1990). Deformación de la boca en un juvenil de Atherinops affinis (Ayres) (Pisces: Atherinidae) desarrollado en laboratorio. Investigaciones Marinas CICIMAR 5, 143-146.

\section{Figures}

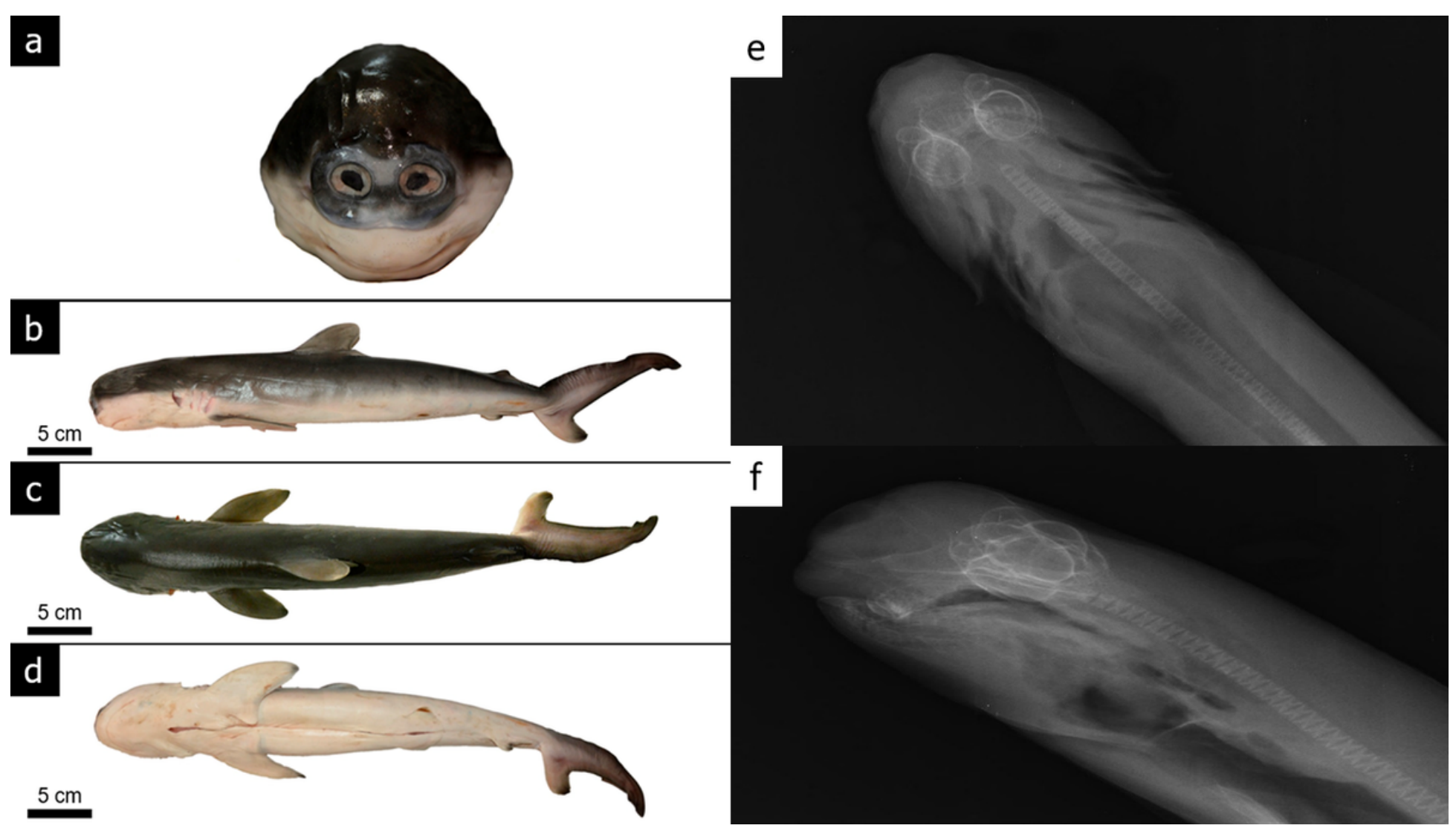

\section{Figure 1}

External \& X-ray images on the deformed silky shark embryo (a) Front view showing snout reduction, lack of nostrils and position of the eyes (b) Side view of embryo showing regular lateral form (c) dorsal surface (d) ventral surface (e) X-ray image showing deformities in the structure of the gill arches (f) X-ray image showing signs of prognathism in the jaw. 